\title{
LEGAL LIABILITY REGARDING THE REGIME OF ORGANIZATION, SYSTEMATIZATION AND SIGNALIZATION OF ROADS IN ROMANIA
}

\author{
Lucian Ioan TARNU \\ "Lucian Blaga" University of Sibiu, Romania \\ lucian_tarnu@yahoo.com
}

\begin{abstract}
People and society's life can not be understood out of conduct rules that must be respected by everybody.

Legal liability represents both a fundamental form of law and a basic component of the whole legal system. One of the fundamental principles of law is liability.

Those who break legal rules alter laws and citizens' legal rights and interests. They disturb, sometimes in a serious way, public order and good going, thus, endangering the most important values of society.

Either the frequency or severity of breaking laws or their negative impact on social balance and legal order oblige law makers to both set up accurately the limits of liability regarding these commitments and penalize them promptly.

Road safety refers to the whole acts and measures submitted in order to improve people s conduct, vehicles and road infrastructure. All these will generate safe conditions for everybody who uses public roads. In this way, the risk of being involved in car crashes with severe consequences will be diminished.
\end{abstract}

Key words: liability, infringement, guilt, systematization, signalization.

1. General issues regarding legal and criminal liability and infringement

Legal liability was defined in the legal theory as "a legal situation of express warning of certain law issues about the legal consequences of breaking legal rules and, if the actual norms are not respected, about the application of constraint of state corresponding to the constant law breaking" [1].

Under these circumstances, legal liability acquires a very special significance, because its meaning is to ensure stability and order in society [2].

Legal liability is a legal relation created by legal rules between the person who violated law and the State which is represented by law enforcement authorities [3].
The content of this special type of legal report consists of: the state's right to apply sanctions under legal rules to people who violated law and the obligation of these people to respect legal sanctions, in order to restore the rule of law.

\section{Conditions of legal liability}

Legal liability can be generated only if three conditions are met as follows: misconduct, fault and causation.

Misconduct represents the concrete behavior - action or lack of action - by which a person violates the law.

Illegal character is determined only in relation to the limitation contained in legal rules.

Guilt means the mental attitude of somebody who commits an illegal deed 
related to both the deed he commits and the consequences of the deed [4].

Other authors in law field define guilt as "the mental attitude of somebody who, committing with an unconstrained will a deed that represents a social danger, had, at that moment, the representation of deed and of its consequences that was socially dangerous or, although he did not have the representation of deed and its consequences, he had the real, subjective possibility of this representations [5].

The forms of guilt are the following: intention, fault, exceeded intention.

Intention, is divided into two forms namely, direct and indirect intention. Fault, has two forms, meaning negligence and imprudence

Exceeded intention

As the legislator did not define clearly the exceeded intention, this task falls under the legal doctrine [6].

So, we can define exceeded intention as a mixed form of guilt which brings together subjectivity of the same infringement, intention and fault, and which occurs when perpetrator, by his deed, foresees, follows or accepts the production of a particular outcome which is socially dangerous. But in reality, it produces a more serious effect or an extra one that perpetrator has foreseen, but has not accepted, believing without reason, that it will not happen, or he has not provided, although he should or could have to [7]. For example, there will be an exceeded intention if perpetrator intends to injure a person. The victim is punched, falls down, hits the road and dies. In legal practice in Romania, there are also cases in which Courts take into consideration infringement referring to injuring the body causing death afterwards [8].

Causal relation between the committed deed and its outcome, is the third essential condition for legal liability, seen as an objective condition.

\section{Penal liability, a form of legal liability}

Penal liability is a form of legal liability and it represents is a legal relation of constraint, generated as a result of infringement [9].

Penal liability is a set of rights and reciprocal obligations of subjects related to penal law, which is achieved primarily by the State constraint to perpetrator, under the conditions and forms provided by law, in order to restore legal order and socially integrate perpetrator [10].

On one hand, it is established between the State and perpetrator, and on the other hand, it is the result of disregarding the provisions of legal rules.

Infringement, once committed, is the only and sufficient basis for penal liability.

It is sufficient to establish the existence of an infringement so that the penal liability should be generated.

The definition of infringement is found in the Penal Code as follows: "infringement is the deed that falls under penal law, committed with guilt, unreasonable and imputable to the person who commits it [11].

Infringement is the only basis of penal liability [12]."

The active subject of penal liability is the State, because it is empowered to exercise constraint on perpetrator who is considered a passive subject because penal sanction is applied to him;

The passive subject of penal liability is always the active subject of the infringement, meaning that the individual is guilty of both committing and participating at an infringement;

Penalty, as typical sanction of penal law, differs from all other legal penalties because it is the hardest form of constraint, because it may refer to both individual's property and freedom.

Penal sanctions, no matter if they refer to a fine, confiscation, imprisonment, etc., do not have a recovering character. They aim to prevention and justice.

The identification of penal liability is done by the identification of infringement by the judicial specialized authorities of the State. Removing penal liability should not be considered an arbitrary act of will of the State authority, it is strictly related and 
determined by general and specific causes.

By adopting the new Penal Code, starting on January, $2^{\text {nd }}, 2014$, it was introduced a series of new institutions beside the other national legal ones. There was brought also a number of important changes to existing institutions according to the previous regulation.

Thus, there were reformed the causes of removing penal nature of the deed, the legislator opted for dividing them into two categories:

1. justifying causes - they are circumstances which remove the third of the essential characteristics of infringement, the unjustified character respectively; the unjustified nature of the deed falling under the penal law assumes that it is not permitted by law, in other words, it is illegal.

2. not-imputable cases - they are circumstances which remove the fourth of the essential characteristics of the infringement, meaning imputation, respectively; not-imputable causes are personal causes, which do not occur to participants, excepting the forcing cases. They will be in the benefit for only the person who acts as such.

The justifying causes [13] are the following: self-defense; state of emergency; exercise a right or achieve an obligation; the harmed person 's approval;

Not-imputable causes are the following: physical constraint; moral constraint; imputable excess; perpetrator's underage; irresponsibility; intoxication; error; forcing event.

\subsection{Penal liability of legal persons [14]}

The Penal Code of Romania regulates very clearly in the Title VI, Chapters I, II and III, penal liability of legal persons.

Thus, the conditions of legal liability are presented in the following statement: "Legal persons, except the State and public authorities, is criminally responsible for infringements committed in order to carry out the activity or in the interest or on behalf of the legal person" [15].
Also, the legal text specifies that "public institutions are not criminally responsible for infringements committed in the exercise of an activity that may not fall under the private domain [16]".

Penal liability of legal persons does not exclude penal liability of natural persons who contributed to committing the same deed [17].

Penalties for legal persons are main and complementary. The main penalty is the fine.

The additional penalties that can be applied to legal persons are the following: dissolution of legal person; suspension of whole activity or of one activity of a legal person for a period from three months to three years; closure of some work spots of legal persons for a period of three months to three years; prohibition to participate at procedures of public procurement for a period of three months to three years; place legal person under judicial supervision; display or publication of the judgment of conviction;

Infringements of road traffic represents all the deeds, by whose criminality, it is protected mainly social values that are represented by security and traffic safety on public roads, defense of life, integrity and health of people and the defense of property of individuals and legal persons .

The terms of "Infringements against the security of road traffic" or "Traffic infringements" are no longer an intellectual creation or jurisprudence because, starting with January, 2 $2^{\text {nd }}, 2014$, when the new Penal Code is enforced, it is known that our penal code includes at the Title VII "Infringements against public safety" and Chapter II "Infringements against traffic safety on public roads" the regime of traffic infringements. These antisocial deeds that represent infringements regarding the organization, systematization and signalization of roads, are provided in Articles 339 and 341 of the Penal Code. 
4. Infringements regarding the organization, systematization and signalization of roads

\subsection{Article 339 of the Penal Code}

\subsubsection{The legal content of infringement}

Infringement falling under the Article 339, paragraph 1 of the Penal Code consists in: "install road signals or change their position, without a permit issued by the competent authorities could mislead road users or hinder traffic on public roads".

In paragraph 2, Article 339 of the Penal Code, it is provided another way of committing an infringement that is

"drivers" participation at unauthorized vehicle competition on public roads".

In paragraph 3, Article 339 of the Penal Code, it is provides that "the penalty provided in paragraph 2 can be applied to placing obstacles that hinder or put in difficulty the traffic on public roads, if it endangers traffic safety or affects the right of free movement of other road users".

In paragraph 4, Article 339 of the Penal Code it is added a way of producing this infringement, namely: "leaving unsupervised on public roads a vehicle carrying goods or dangerous substances. This is penalized with imprisonment from 1 to 3 years."

\subsubsection{Preexistent conditions}

Object of infringement [18]

a) the specific legal object is represented by those social relations whose occurring, normal progress and development depend on security and safety on public roads.

b) the material object of infringement is the organizational elements, signalization and systematization of traffic on public roads.

Thus, as provided in paragraph 1, it is about the subject material and it consists of "traffic signalization means".

In order to be considered a material object, these means must be legally placed, not undergo a change or injury in their substance, potential and possibility of usage.
In this respect, it is not irrelevant if they are in perfect condition or have a certain degree of usage, the essential condition being that they are usable and visible.

Also, in this variant of infringement, the material object can be represented even by roadway, as an essential element of public roads.

The material object of infringement may be public roads themselves as mentioned in paragraph 3, Article 339 of the Penal Code.

We believe that the legislator intended to include in the material object all the traffic signalization means, obliging drivers to make certain maneuvers or prohibiting the change of the driving directions. Any change in marking an intersection can endanger safety.

The "road arrangement" means any object located on the roadway or in its area, designated to regulate traffic movement [19].

"Vehicle" [20] means a mechanic system moving on the road, with or without engine, normally used for transporting people and/or goods to perform services or works. The material object can be structured through the creation of obstacles on roadway. The obstacles that can be created were not individualized by the legislator, due to which any change in roadway may be considered obstacle if it endangers road safety.

\section{Subjects of infringements}

a) an active subject of infringement may be any natural person who meets the general conditions of penal liability, except those who have got the authorization issued by the competent authorities for such activities.

Participation is possible in all its forms as follows: the same authors, instigation, complicity. Under the new Penal Code, active subject may be a legal person [21].

b) a passive subject of this infringement is the State as guarantor and permanent protector of social values protected by law. Also, the passive subject may be any person whose life, physical integrity or 
health is in danger or right to free movement is altered [22].

\subsubsection{Constitutive content [23] Objective side}

a) the material element of the objective side of the infringement falling under Article 339,

paragraph 1 of the Penal Code, consists in either installing road signalization means or changing their positions, without a permit issued by the competent authority in this area. The installation or similar installations should not cover road signalization means, which could mislead road users.

By changing road traffic signalization means, that do not have to correspond to their initial destination, thus, creating rights and obligations regarding public roads movement for other road users than those referred to when the installation was made. In the variant mentioned in paragraph 1 , Article 339 of the Penal Code, the material element consists of either installing road signalization means or changing their position.

The existence of infringement is conditioned by misleading road users, making traffic on public roads difficult, even producing a crash that may have been caused by the installation or change of the position of the traffic signalization means.

As far as paragraph 2, Article 339 of the Penal Code is concerned, the material element is the participation, as a driver, at authorized competitions on public roads.

The participation at an unauthorized competitions means that the latter take place on public roads to endanger road safety or affect the right of free movement of other road users.

In paragraph 3, the material element consists of placing obstacles on the public road. The essential requirement is not to hinder or make difficult the movement on the public roads if this kind of obstacles endangers traffic safety or affects the right to free movement of other road users.

As far as infringement stipulated in paragraph 4 is concerned, the material element consists of leaving on the road unsupervised vehicles carrying dangerous goods or substances.

\section{b) essential requirements}

In order to reach the objective side of infringements stipulated in paragraph 1, Art. 339 of the Penal Code, action or actions of installing and modifying traffic signalization means should be carried out or done without the authorization issued by the competent authorities.

If these activities are authorized by the competent authorities, the deeds will not be considered infringements.

As far as the paragraphs 2, 3 and 4 are concerned, action or actions must take place on a public road in line with the content of Art. 75 of the Government Emergency Ordinance no.195/2002, republished. This requirement also applies to infringements stipulated in paragraph 1 . The requirement mentioned in paragraph 4 is that vehicles should carry goods or dangerous substances.

\section{c) immediate consequence}

As far as infringement stipulated in paragraph 1, Article 339 of the Penal Code is concerned, the immediate consequence refers to a negative transformation of the means of organization and systematization of usage capacity they had before committing infringement and, thus, road users are misled, the traffic is hardened and safety of road traffic is endangered.

The immediate consequence of infringement referred to in paragraphs 2, 3 and 4, Article 339 of the Penal Code, is putting in danger traffic safety by hindering traffic on public roads, by altering the free movement of road users by placing on public roads some objects or vehicles, by participating at unauthorized contests or competitions or by leaving unsupervised vehicles that transport goods or dangerous substances.

\section{d) casual relation}

Between any of the actions that can form the material element and the immediate consequence, there must be a casual relation so that an infringement occurs. 
Subjective side

Infringement is committed only intentionally, directly or indirectly. If the deed is committed by fault, this is no longer an infringement, the legislator expressly providing the necessity of the intention in committing it.

\subsubsection{Forms. Ways. Sanctions Forms}

a. Infringement, in all its variants, can exist in all imperfect forms of infringement, but the preparatory deeds and the attempt are not penalized by penal law.

b. The committing of infringement. Infringement is committed when the action came to the end and the immediate consequence was produced, i.e. the safety of road traffic was endangered by misleading the traffic participants or hinder the traffic. Thus, there was a crash or the right to free movement of other road users was altered.

c. Exhaustion. Infringement can be committed repeatedly, so the exhaustion occurs once with both committing the final deed of the penal activity and eliminating the exposure to danger.

Ways.

Infringement has several ways of achieving, i.e. installing or modifying traffic signalization means in paragraph 1; participation at unauthorized competitions in paragraph 2; positioning obstacles in paragraph 3; leaving on the main road an unsupervised vehicle carrying dangerous products or substances in paragraph 4.

\section{Sanctions}

As far as infringement referred to in all variants in Art. 339 of the Penal Code is concerned, penalty is imprisonment from three months to two years or fine.

4.2. Article 341 of the Penal Code

4.2.1. The legal content of infringement An infringement falling under Article 341, paragraph 1 of the Penal Code refers to "carrying out some building works, modification, modernization or rehabilitation of public roads or rearrangement of the access to public roads without a building permit issued in compliance with law or without respecting the conditions stated in the permit."

The form stipulated in paragraph 2 of the Penal Code states that "the placement of buildings, panels or advertisements on the road without building permit issued in compliance with law or without respecting the conditions stated in the permit, if, due to this, it is generated a danger towards the road traffic safety".

According to paragraph 3, Article 341 of the Penal Code, it is established a penalty for "person authorized by the administrator of railways who does not take the proper measures for the signalization of the railway level crossings".

According to paragraph 4, it is established a penalty for "person authorized by the administrator of public roads or by the performer of works on the roadway, who does not take appropriate measures for signalization of obstacles or works on public roads, if due to this there happened a traffic accident."

\subsubsection{Preexistent conditions}

\section{Object of infringement}

a) the legal object of infringement is the social relations regarding legal provisions concerning the authorization or approval of issuing the permit for building, modernization or rehabilitation of public road or arrangement of the access to public roads; also, the legal object is represented by the location of buildings, panels or advertisements on the road, violating the conditions set by police specialized in arranging access to public roads and failing to take measures to signalize the railway level crossings or modifying this signalization without the approval of the specialized police.

b) the material object of infringement consists of the authorization issued without the police specialized approval, the building sites placed on the road without respecting the conditions laid down by police specialized in arranging road access or the inadequate signalization at the 
railway level crossings, all of these being elements of organization and systematization of the road traffic.

\section{Subjects of the infringement}

a) the active subject of infringement referred to in paragraph 1, Article 341 of the Penal Code can be any person who meets the general conditions of penal liability and who is involved in building site works, modification, modernization or rehabilitation of public roads or arrangement of access to public roads without building permit issued in compliance with law or without respecting the conditions mentioned in the permit.

Also, the active subject can be a qualified subject. This quality is specific only to the persons authorized by law to issue permit for building site works, modification, modernization or rehabilitation of public roads or arrangement of the access to public roads.

These persons are the representatives of the Ministry of Transport, county or local councils, in their capacity as administrators of public roads.

In line with the variant provided in paragraph 2, an active subject may be any person who meets the general conditions of penal liability and who places building site panels or advertisements on the road without building permit issued in compliance with law or without respecting the conditions of the permit, if, by this, road traffic safety is endangered.

Participation is possible in all its forms (the same perpetrator, instigation, complicity).

An active subject of infringement as referred to in paragraph 3, Article 341 of the Penal Code is a qualified subject and he can only be authorized person who has among job responsibilities the measures taking to signal railway level crossings.

Referring to paragraph 4, the active subject of infringement is also a qualified one represented by an agent of the public road administrator, be him the authorized person or the building site work performer who breaks the law by lack of action or by not taking appropriate measures for signalization of the obstacles or building site work on public roads.

b)the passive subject is the state as guarantor and protector of social values protected by law.

At the same time, the passive subject may be any natural or legal person who was harmed as a result of infringement.

\subsubsection{Constitutive content \\ Objective side}

a) the material element of the objective side of infringement referred to in paragraph 1, Article 341 of the Penal Code, is the act of "performing building works, rearrangement, modernization or rehabilitation of public roads or arrangement of the access to public roads without building permit issued in line with law or without respecting the conditions mentioned in the permit".

Issuing a building permit is expressly regulated by law and requires, at its turn, a series of permits and authorizations from public institutions such as the authorities administrating energy, gas, water, sewerage, sanitation, environmental protection, etc. An important and also a fundamental condition is that of obtaining the permit and traffic police approval.

The issued permit must be for building site works, rearrangement, modernization or rehabilitation of public roads or arrangement of the access to public roads.

The material element of infringement provided in paragraph 2 is materialized by placing buildings, panels or advertisements on public roads without building permit issued in compliance with law or without respecting the conditions stated in the permit, if, thus, safety road is endangered. This can be achieved only through action.

The material element of infringement referred to in paragraph 3 may be accomplished both by action and lack of action. The action materializes in the change of the signalization of the railway level crossings without the permit of traffic police. 
Also, the material element is achieved even if there is the specialized police consent, but, changing the signalization in another way than the one the consent was given for. The lack of action materializes in not taking measures for signalization of the railway level crossings.

The signalization by different means does not eliminate the production of the material element of infringement. In this case, it falls under paragraph 1, Article 339 of the Penal Code. Only one activity from those mentioned above is sufficient so that an infringement occurs.

The material element of infringement referred to in paragraph 4 is similar to the one mentioned in paragraph 3 . The only difference between them refers to the road administrator or a person authorized by the administrator, who can be an authorized person or a performer of building works.

The action materializes in the signalization of the obstacles or of works on public roads without the traffic police approval, if, thus, a crash occurs.

b)essential requirements. In order to reach the objective side of infringement as referred to in

paragraphs 1and 2, Article 341 of the Penal Code, it is mandatory that the activities foreseen in the legal text to be done without the existence of the building permit.

The permit issued by traffic police must be in writing, clearly stating the activities, the way and their deadlines for which the consent is issued.

Exceptionally, on emergency situations, the consent may be given verbally in order to start the activities. Afterwards, it will be confirmed in writing.

If the activities that represent the material element of the objective side develop with the consent of traffic police, the deeds are not considered infringements.

This requirement shall not apply to infringements referred to in paragraph 3 and in the first sentence of paragraph 4 of the Article. c) immediate consequence of infringement referred to in paragraphs 1 and 2 is the danger of the traffic flow and safety due to the conditions imposed by the building site permit for the access to public roads in case of building sites located in the road area.

The consequence is conditioned by a permit that enables the performance of building works, rearrangement, modernization or rehabilitation of public roads, arrangement of the access to public roads, placement of panels or advertisements on the road. It occurs when the performer of such works gets the permit, thus gaining the right to perform such work.

In line with the variant mentioned in paragraph 3 , the immediate consequence is the existence of a railway level crossings unmarked or improperly flagged.

In line with the variant mentioned in paragraph 4 , the immediate consequence is the production of a crash lest law should distinguish expressly the seriousness or consequences of the crash.

\section{d) casual relation}

Between any of the actions that can form the material element and the immediate consequence, there must be a casual relation referring to the production of infringement.

The specific actions of infringement do not always produce immediate consequence. In this case, they represent contraventions, being prosecuted and penalized in line with the contravention law [24].

\section{Subjective side}

In all the variants of infringement referred to in Article 341 of the Penal Code, the committing of infringement must be intentional, direct or indirect. The activities that form the material element of infringement are not likely to be committed with fault.

\subsubsection{Forms. Ways. Sanctions Forms}

a)Infringement, in all its variants, can take of all forms of imperfect infringement, but 
the deeds of preparation and the attempt are not punishable under penal law.

b) The committing of infringement. Infringement is committed when the execution of criminal deed came to its end and the immediate consequence occurs. This means that the permit for one of the works listed above was issued, the flow and security of traffic was endangered or there was a railway level crossing unmarked or incorrectly signaled.

c) Exhaustion. Infringement can be committed repeatedly, in which case exhaustion occurs once with committing the final part of the criminal deed or eliminating the exposure to the created danger.

Ways

Infringement has several legal ways, namely: performing some building works, rearrangement, modernization or rehabilitation of public roads or arrangement of the access to public roads; placement of buildings, panels or advertisements on the road; not taking appropriate measures for the signalization of railway level crossings; not taking appropriate measures for the signalization of obstacles or of road works.

Each of these legal ways can meet a variety of factual ways.

\section{Sanctions}

As far as infringement mentioned in Article 341, paragraph 1 of the Penal Code, penalty is imprisonment from six months to three years or a fine. For any of the variants specified in paragraphs 2,3 and 4 , penalty is imprisonment from three months to one year or a fine.

\section{Conclusions}

Coding traffic infringements supposes and generates such a thinking which is homogeneous, correct and related to principles and rules clearly defined, interrelated and harmonized with legal instruments, concepts and international standards in this field.

In our opinion, this new regulation is a good and also efficient in terms of research and achievement of resolution, and the main consideration for which they were transferred to a special law and introduced the new Penal Code is that of treating them as the deeds of a high social danger.

The experience has shown that in the Penal Code should be included only those accusations that should be less amended.

Some of the deeds that are against laws concerning the organization, systematization and signalization of road traffic represent a serious danger to road safety and flow, which leads that they should be established and penalized as infringements.

\section{REFERENCES}

[1] Gliga, I., Aspects Concerning the Definition of Legal Liability, in Studia Univesitatis, Babes Bolyai, Series jurisprudentia, Cluj Napoca, 1970, p. 98-99;

[2] Voicu, Costică, Voicu, Adriana Camelia, General Theory of Law, Universul Juridic Publishing House, Bucharest, 2013, p 257;

[3] Ibidem, p. 257;

[4] Ibidem, p. 258;

[5] Dobrinoiu, V., Pascu, I., Lazăr, V., Nistoreanu, Ghe., Molnar, I., Boroi, A., Penal Law, General part, Atlas Lex Publishing House, Bucharest, 1994, p. 96;

[6] Ibidem, p 103;

[7] Ibidem, p 103;

[8] The Supreme Court, Penal Section, sentence no. 434 from March, 5th, 1987.

[9] Voicu, Costică, Voicu, Adriana Camelia, cit.ed, p 259;

[10] Dobrinoiu, V., Pascu, I., Lazăr, V., Nistoreanu, Ghe., Molnar, I., Boroi, A., Penal Law, General part, Atlas Lex Publishing House, Bucharest, 1994, p. 316; 
[11] Art. 15, paragraph. 1 of the Penal Code;

[12] Art. 15, paragraph 2 of the Penal Code;

[13] Title II, Chapter II, art 18-22 of the Penal Code;

[14] Voicu, Costică, Voicu, Adriana Camelia, cit.ed, p 262;

[15] art 135, paragraph 1 of the Penal Code;

[16] art 135, paragraph 2 of the Penal Code;

[17] art 135, paragraph 3 of the Penal Code;

[18] Tarnu, Lucian Ioan, Legal Aspects legislative of Systematization and Signalization of Road Traffic in Romania, „Lucian Blaga” University in Sibiu Publishing House, 2016, p. 115;

[19] Turianu, C., Road Traffic Infringements, All Beck Publishing House, Bucharest, 2000, p.119.

[20] Breban, V., Dictionary of the Romanian Language for Internal Usage, Ştiinţifică şi Enciclopedică Publishing House, Bucharest, 1980, p.184;

[21] See the section above refering to legal liability of legal person;

[22] art. 25 of the Constitution of Romania;

[23] Tarnu, Lucian Ioan, cit.ed, p. 116;

[24] The Government Ordinance no.2/2001, regarding the legal regime of contraventions; 